\title{
Cradle-to-gate life cycle assessment of energy and carbon of a residential building in Sri Lanka
}

\author{
Ramya Priyangani Kumanayake ${ }^{12^{*}}$ and Hanbin Luo ${ }^{2}$ \\ ${ }^{1}$ Department of Civil Engineering, General Sir John Kotelawala Defence University, Ratmalana. \\ ${ }^{2}$ School of Civil Engineering and Mechanics, Huazhong University of Science and Technology, 1037 Luoyu Road, Wuhan 430074, China.
}

Revised: 28 January 2018; Accepted: 23 March 2018

\begin{abstract}
The growing concerns over the environment have led to increasing demand for environmentally-friendly buildings. So far, only a few studies on environmental impacts of buildings have been conducted in the context of Sri Lanka. Reliable data sources that match the specific conditions of the country are limited. Using the life cycle assessment (LCA) methodology, this paper presents a cradle-to-gate energy and carbon emission study of a multi-storey residential building in a Sri Lankan university. The total embodied energy and carbon of the building are $3.84 \mathrm{GJm}^{-2}$ and $229.34 \mathrm{kgCO}_{2} \mathrm{~m}^{-2}$, respectively, which are comparable with results of similar studies found in literature. Reinforced concrete, the main structural material, contributed to $61 \%$ of total embodied energy and $71 \%$ of total embodied carbon of the building. Despite the relatively low material quantity used, aluminium, ceramic tiles and paint shared $18.67 \%$ of total embodied energy. In order to achieve low-energy and low-carbon buildings in Sri Lanka, several strategies were identified; suitable construction practices and building designs to reduce quantities of mass materials, use of alternative materials with low energy and carbon intensities, material recycling and reuse, use of clean and renewable energy for production processes and popularising the concept of eco-labels for building materials. The reduction of embodied energy and carbon is expected to lighten the environmental footprint of buildings.
\end{abstract}

Keywords: Building materials, cradle-to-gate, embodied carbon, embodied energy, life cycle assessment.

\section{INTRODUCTION}

Buildings have a significantly high environmental footprint. They are responsible for more than one third of the global energy-related greenhouse gas (GHG) emissions and in most countries, are the largest emission source (UNEP, 2009). Therefore, buildings play an important role in global initiatives for mitigating adverse environmental impacts and promoting sustainable development. For any improvement to take place, assessment of the current building performance is essential. Among many approaches of building environmental assessment, life cycle assessment (LCA) which considers a range of environmental impacts throughout the lifetime of a building is considered the most appropriate. The global GHG emissions due to human activities including construction have grown since pre-industrial times, with an increase of $70 \%$ between 1970 and 2004, during which the annual emissions of carbon dioxide, the most important anthropogenic GHG grew by about $80 \%$ (IPCC, 2007). Life cycle energy and carbon emission assessment has become significant due to the imminently threatening issue of global warming caused by GHG emissions.

Most of the past research on building energy and carbon emission assessment focused on developed and temperate countries, and only a few examples of developing, tropical countries exist (Dias \& Pooliyadda, 2004; Kofoworola \& Gheewala, 2008; Shukla et al., 2009; Venkatarama Reddy, 2009; Ramesh et al., 2012a; Varun et al., 2012). As energy and carbon emission data of buildings vary highly from one country to another over a wide range of factors, the importance of using countryspecific data to reflect the exact conditions of a country

*Corresponding author (ramyak@hust.edu.cn; (D) https://orcid.org/0000-0003-4531-1518) 
in energy and carbon emission studies is emphasised. In most of the previous studies based on developing tropical countries, already available energy and carbon emission data were used. Some researchers attempted modification of available data to reflect the uniqueness of their own countries (González \& García Navarro, 2006; Chau et al., 2007; Abeysundara et al., 2009). Some of the factors, which require special attention when applying existing research findings to the developing, tropical countries were identified as; the level of operational energy use, transition from traditional to modern building materials, role of insulation, role of advanced building systems, technology of material production, energy production methods and energy carriers (Ruuska, 2013).

The energy consumption in Sri Lanka is steadily rising and an increase of carbon dioxide emissions nearly four times from 1990 to 2015 was recorded (European Commission, 2016). Construction is the second largest industry of the country and contributes to a significant amount of energy consumption and GHG emissions. As buildings contribute to more than $50 \%$ of the value of work done and raw materials used in the construction sector (Department of Census and Statistics Sri Lanka, 2015), assessment of environmental implications of buildings should be considered a priority. Only a few building life cycle environmental assessment studies were conducted to date in the context of Sri Lanka and the available quantitative information is limited. This paper presents a 'cradle-to-gate' partial life cycle assessment of a residential building in a Sri Lankan university in terms of embodied energy and carbon. The methodology applied in the study can be used to assess the environmental impacts of building materials in early design stage, which will help decision makers in selecting the most environmentally- friendly materials for a particular building design.

\section{Case study}

The newly constructed, multi-storey student accommodation building in the General Sir John Kotelawala Defence University, Ratmalana, Sri Lanka was considered for cradle-to-gate life cycle assessment. It is a reinforced concrete structure having a total floor area of $1968 \mathrm{~m}^{2}$ with 113 rooms. The ground floor consists of a porch, lobby, 18 bed rooms, bathrooms and a work unit. The $1^{\text {st }}$ to $5^{\text {th }}$ floors are identical and each comprises a lobby and 19 bed rooms with balconies and bath rooms. A concrete-brick water tank is installed at the roof level. The basic parameters of the building are given in Table 1 .

Table 1: Basic parameters of case study building

\begin{tabular}{ll}
\hline Building parameter & Specification \\
\hline Number of floors & 6 floors \\
Gross floor area & $1968 \mathrm{~m}^{2}$ \\
Total height & $18 \mathrm{~m}$ \\
Service life & 50 years \\
Structure & Reinforced concrete \\
Envelope & Brick masonry \\
Foundation & Reinforced concrete and random rubble masonry \\
Walls & Brick masonry \\
Roof & Steel truss with corrugated asbestos cement roofing sheets \\
Ceiling & Timber framework with asbestos ceiling panels \\
Doors and windows & Timber, plywood, aluminium and glass \\
Finishes & Ceramic tiles, cement sand rendering, cement plaster and painting \\
\hline
\end{tabular}

The front elevation and the ground floor plan of the building are illustrated in Figure 1.

\section{METHODOLOGY}

As the study presents a LCA, the four stages of the LCA methodological framework as identified in ISO
14040 on Environmental Management (ISO, 1997) were followed, which include goal and scope definition, inventory analysis, impact assessment and interpretation. The LCA was process-based where the input data in the form of energy and materials were utilised in assessing the environmental impacts in terms of embodied energy and carbon. 


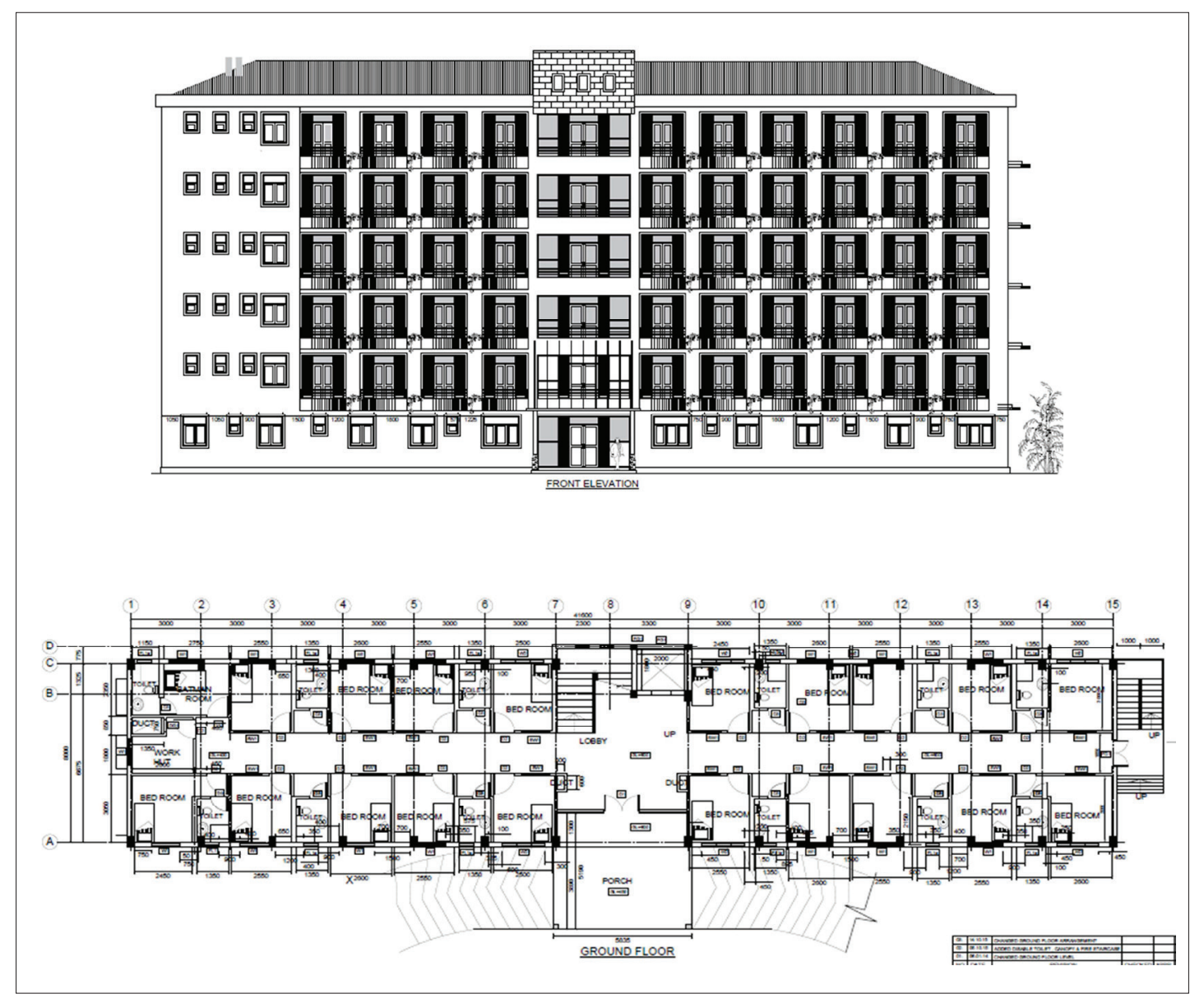

Figure 1: Front elevation and ground floor plan of the building

\section{Goal and scope of the study}

The goal of the study was to assess the cradle-to-gate life cycle energy and carbon emission of a multistorey student accommodation building in a Sri Lankan university. Both spatial and life cycle process boundaries were included within the system boundary of the study. The spatial boundary was defined as the closed threedimensional space bounded by the foundation, roof and façade of the building. Only the main materials used for building structure, envelope and finishes were considered and temporary works, building services and furnishing were excluded. The relevant phases of the cradle-to-gate life cycle such as raw material extraction, transportation, refining, processing and fabrication until the building material leaves the factory gate, were included in life cycle process boundary. The functional unit of the study was considered as one square meter $\left(\mathrm{m}^{2}\right)$ of gross floor area of the building.

\section{Life cycle inventory analysis}

According to ISO 14040 (ISO, 1997), inventory analysis involves data collection and calculation procedures to quantify relevant inputs and outputs. The inputs (materials and energy) and outputs (embodied energy and carbon emission) during cradle-to-gate building life cycle were considered in the life cycle inventory. The inputs were obtained from design drawings, bill of quantities, technical specifications as well as the reports of relevant Sri Lankan and international bodies. In the case of insufficient data, suitable assumptions were made with consultation of experienced construction professionals. A detailed estimation of the main building materials was carried out. For the conversion of the basic material quantity $\left(\mathrm{m}^{3}, \mathrm{~m}^{2}\right.$ or $\left.\mathrm{m}\right)$ into mass, the characteristics of materials specified by the manufacturer and relevant standards were taken into account. In cases where this is not possible due to the complexity of work unit, each work unit was divided into simple material units. 
The embodied energy and carbon of a building material vary from one country to another depending on factors such as the raw materials used, material production technologies, energy sources and quality of energy. In Sri Lanka, a wide range of energy sources are used to manufacture building materials - from firewood for brick production to fossil fuel and electricity for cement production (Emmanuel, 2004). In estimating embodied energy and carbon of materials these country-specific factors should be taken into account.

In the present study, values of embodied energy and carbon emission coefficients were taken from existing Sri Lankan literature (Pooliyadda, 2000; Dias \& Pooliyadda, 2004) as much as possible. Whenever the data available in these sources did not match with the specifications of materials considered in the study, Inventory of Carbon and Energy (ICE) version 2.0 database developed by the University of Bath, UK (Hammond \& Jones, 2011) was referred.

\section{Calculation of embodied energy and carbon}

The life cycle inventory data were used to calculate the embodied energy and carbon of the cradle-to-gate life cycle of the building by applying formulae (1) - (4) (Chau et al., 2015).

The cradle-to-gate embodied energy of a material includes embodied energy of extraction, transportation of raw materials and material manufacturing.

$$
\begin{gathered}
E_{\text {embodied }, i}=E_{\text {extraction }, i}+E_{\text {transportation }, i} \\
+E_{\text {manufacture }, i} \\
E_{\text {embodied }}=\sum_{1}^{i} \propto_{i} m_{i}
\end{gathered}
$$

$E_{\text {embodied, },}$ and $E_{\text {embodied }}$ are the embodied energies (MJ) of building material $i$ and the building, respectively. $\alpha_{i}\left(\mathrm{MJkg}^{-1}\right)$ and $m_{i}(\mathrm{~kg})$ are the embodied energy coefficient and mass of building material $i$, respectively.

The cradle-to-gate embodied carbon of a material includes embodied carbon of extraction, transportation of raw materials and material manufacturing.

$$
\begin{aligned}
\mathrm{CO}_{2, \text { embodied }, i}= & \mathrm{CO}_{2, \text { extraction }, i}+\mathrm{CO}_{2, \text { transportation }, i} \\
& +\mathrm{CO}_{2, \text { manufacture }, i}
\end{aligned}
$$

$$
\mathrm{CO}_{2, \text { embodied }}=\quad \sum_{i}^{i} \beta_{i} m_{i}
$$

$\mathrm{CO}_{2, \text { embodied }, i}$ and $\mathrm{CO}_{2, \text { embodied }}$ are the embodied carbon $\left(\mathrm{kgCO}_{2}\right)$ of building material $i$ and the building, respectively. $\beta_{i}\left(\mathrm{kgCO}_{2} \mathrm{~kg}^{-1}\right)$ and $m_{i}(\mathrm{~kg})$ are the embodied carbon coefficient and mass of building material $i$, respectively.

\section{Life cycle impact assessment}

In this phase, the significance of potential environmental impacts was evaluated using the results of life cycle inventory analysis. In the study, embodied energy and carbon were considered as the potential environmental impacts. The final results were presented as embodied energy per unit gross floor area (in $\mathrm{GJm}^{-2}$ ) and embodied carbon per unit gross floor area (in $\mathrm{kgCO}_{2} \mathrm{~m}^{-2}$ ) of the case study building.

\section{Life cycle interpretation}

This phase combines the findings of inventory analysis and impact assessment to reach conclusions and suggest recommendations within the defined goal and scope of the study.

\section{Limitations}

Most of the embodied energy and carbon coefficient values required for the study were taken from the existing Sri Lankan literature. Some data were referred from international databases such as the Inventory of Carbon and Energy (ICE). As the embodied energy and carbon of materials vary from country to country, data from ICE database that mainly focuses on UK construction industry may not be fully compatible with the raw materials, manufacturing technologies and energy sources used in Sri Lanka, which can lead to inaccuracies in results. In estimating embodied energy and carbon coefficients of materials, previous researchers (Pooliyadda, 2000; Dias \& Pooliyadda, 2004) considered material manufacturing technologies and electricity generation mix of the country prevailing at the time of the respective studies. As these factors vary with time, periodic examination and revision of data to reflect the changes are necessary. The development of a national embodied energy and carbon coefficient database for Sri Lankan building materials is a timely requirement. Such a database can be used for more accurate estimation of embodied energy and carbon of buildings in Sri Lanka. 


\section{RESULTS AND DISCUSSION}

The percentage contributions of construction materials to total building mass are presented in Table 2. The combination of the structural materials; concrete, rubble and reinforcement steel together was about $77 \%$ of the total material mass. Among the materials used for building envelope, cement mortar and bricks contributed highly to total material mass, while the finishing materials which contributed most were cement plaster

Table 2: Summary of materials used in case study building

\begin{tabular}{lrrrrr}
\hline Material & Quantity & Unit & $\begin{array}{r}\text { Density } \\
\left(\mathrm{kgm}^{-3}\right)\end{array}$ & Mass $(\mathrm{kg})$ & $\begin{array}{c}\text { Percentage of } \\
\text { total mass }\end{array}$ \\
\hline Ready-mix concrete & 776.6 & $\mathrm{~m}^{3}$ & 2400 & $1,863,840.0$ & 58.68 \\
Random rubble & 208.0 & $\mathrm{~m}^{3}$ & 2300 & $478,400.0$ & 15.06 \\
Clay bricks & 47694.0 & $\mathrm{nos}$ & - & $109,696.2$ & 3.45 \\
Cement mortar & 144.9 & $\mathrm{~m}^{3}$ & 1900 & $275,234.0$ & 8.67 \\
Reinforcement steel & 89317.6 & $\mathrm{~kg}$ & 7800 & $89,317.6$ & 2.81 \\
Structural steel & 3764.4 & $\mathrm{~kg}$ & 7800 & $3,764.4$ & 0.12 \\
Asbestos & 738.8 & $\mathrm{~m}^{2}$ & 2400 & $10,656.0$ & 0.34 \\
Timber & 1498.3 & $\mathrm{~m}$ & 800 & $6,232.0$ & 0.20 \\
Plywood & 251.4 & $\mathrm{~m}^{2}$ & 600 & $6,036.0$ & 0.19 \\
Aluminium & 499.0 & $\mathrm{~m}^{2}$ & 2700 & $4,239.0$ & 0.13 \\
Glass & 471.8 & $\mathrm{~m}^{2}$ & 2600 & $6,136.0$ & 0.19 \\
Cement plaster & $11,015.1$ & $\mathrm{~m}^{2}$ & 1600 & $282,560.0$ & 8.90 \\
Ceramic tiles & 3384.4 & $\mathrm{~m}^{2}$ & 1700 & $34,680.0$ & 1.09 \\
Paint & $11,857.1$ & $\mathrm{~m}^{2}$ & - & 5389.6 & 0.17 \\
Total & & & & $\mathbf{3 , 1 7 6 , 1 8 0 . 8}$ & \\
\hline
\end{tabular}

Table 3: Embodied energy and carbon of materials

\begin{tabular}{|c|c|c|c|c|c|c|c|}
\hline Material & $\begin{array}{c}C-1 \\
\text { EE } \\
\text { coefficient } \\
\left(\mathrm{MJkg}^{-1}\right)\end{array}$ & $\begin{array}{c}C-2 \\
\text { Embodied } \\
\text { energy } \\
(\mathrm{GJ})\end{array}$ & $\begin{array}{c}C-3 \\
\text { Percentage of } \\
\text { embodied } \\
\text { energy }\end{array}$ & $\begin{array}{c}C-4 \\
\mathrm{EC} \\
\text { coefficient } \\
\left(\mathrm{kgCO}_{2} \mathrm{~kg}^{-1}\right)\end{array}$ & $\begin{array}{c}C-5 \\
\text { Embodied } \\
\text { carbon } \\
\left(\mathrm{kgCO}_{2}\right)\end{array}$ & $\begin{array}{c}C-6 \\
\text { Percentage of } \\
\text { embodied } \\
\text { carbon }\end{array}$ & $\begin{array}{c}\text { Data } \\
\text { source }^{a}\end{array}$ \\
\hline Ready-mix concrete & 0.91 & 1696.08 & 22.46 & 0.14 & 260937.60 & 57.82 & (1) \\
\hline Random rubble & 0.04 & 17.94 & 0.24 & 0.0022 & 1040.52 & 0.23 & (2) \\
\hline Clay bricks & 3.73 & 409.17 & 5.42 & 0.0004 & 47.69 & 0.01 & (3) \\
\hline Cement mortar & 0.97 & 266.98 & 3.53 & 0.156 & 42936.50 & 9.51 & (1) \\
\hline Reinforcement steel & 32.69 & 2919.44 & 38.66 & 0.653 & 58324.39 & 12.92 & (2) \\
\hline Structural steel & 32.69 & 123.04 & 1.63 & 0.653 & 2458.15 & 0.54 & (2) \\
\hline Asbestos & 4.48 & 47.70 & 0.62 & 0.1899 & 2023.58 & 0.45 & (2) \\
\hline Timber & 1.97 & 12.27 & 0.16 & 0.00 & 0.00 & 0.00 & (2) \\
\hline Plywood & 15.00 & 90.54 & 1.20 & 0.221 & 1333.96 & 0.30 & (1) \\
\hline Aluminium & 147.48 & 625.17 & 8.28 & 3.05 & 12928.95 & 2.86 & (2) \\
\hline Glass & 8.34 & 51.17 & 0.68 & 0.166 & 1018.58 & 0.23 & (2) \\
\hline Cement plaster & 1.80 & 508.61 & 6.73 & 0.12 & 33907.20 & 7.51 & (1) \\
\hline Ceramic tiles & 12.00 & 416.16 & 5.51 & 0.78 & 27050.40 & 5.99 & (1) \\
\hline Paint & 68.32 & 368.22 & 4.88 & 1.359 & 7324.47 & 1.62 & (2) \\
\hline Total & & 7552.49 & & & 451331.99 & & \\
\hline
\end{tabular}

a Values of embodied energy and carbon coefficients were taken from (1) ICE database version 2.0 (Hammond \& Jones, 2011); (2) Pooliyadda (2000); (3) Dias and Pooliyadda (2004) 
and ceramic tiles. The other materials such as structural steel, asbestos, timber, plywood, aluminium, glass and paint only made up $1.34 \%$ of the total material mass.

The embodied energy and carbon coefficients, which were taken from existing Sri Lankan literature and the ICE database are given in columns $C-1$ and $C-4$ of Table 3. The process based energy data from previous Sri Lankan studies (Pooliyadda, 2000; Dias \& Pooliyadda, 2004) included three energy components; production, transportation of raw materials and energy embedded in raw materials. In estimating energy and carbon coefficients, country-specific conditions regarding raw materials and energy sources were considered by the researchers. For example, biomass was taken as the energy source for manufacturing clay bricks, for which the carbon emission factor was assumed as zero; hence bricks have a very low carbon emission coefficient according to Sri Lankan data sources $\left(0.0004 \mathrm{kgCO}_{2} \mathrm{~kg}^{-1}\right)$ compared with the respective value in the ICE database $\left(0.24 \mathrm{kgCO}_{2} \mathrm{~kg}^{-1}\right)$. A zero carbon emission coefficient was considered for timber, as carbon emission from the use of timber is compensated by the absorption of atmospheric carbon dioxide by trees during their growth (González \& García Navarro, 2006).

\section{Contribution of building materials}

Reinforced concrete, the main structural material of the building represented the largest component in the total embodied energy and carbon, contributing to $61.12 \%$ of embodied energy and $70.74 \%$ of embodied carbon. The results of previous studies on reinforced concrete structures are in agreement with the high contribution of reinforced concrete to total embodied energy and carbon of a building (Asif et al., 2007; Dimoudi \& Tompa, 2008; Kofoworola \& Gheewala, 2008; Biswas, 2014; Hong et al., 2015). The comparison of percentage mass and embodied carbon for different materials is illustrated in Figure 2.

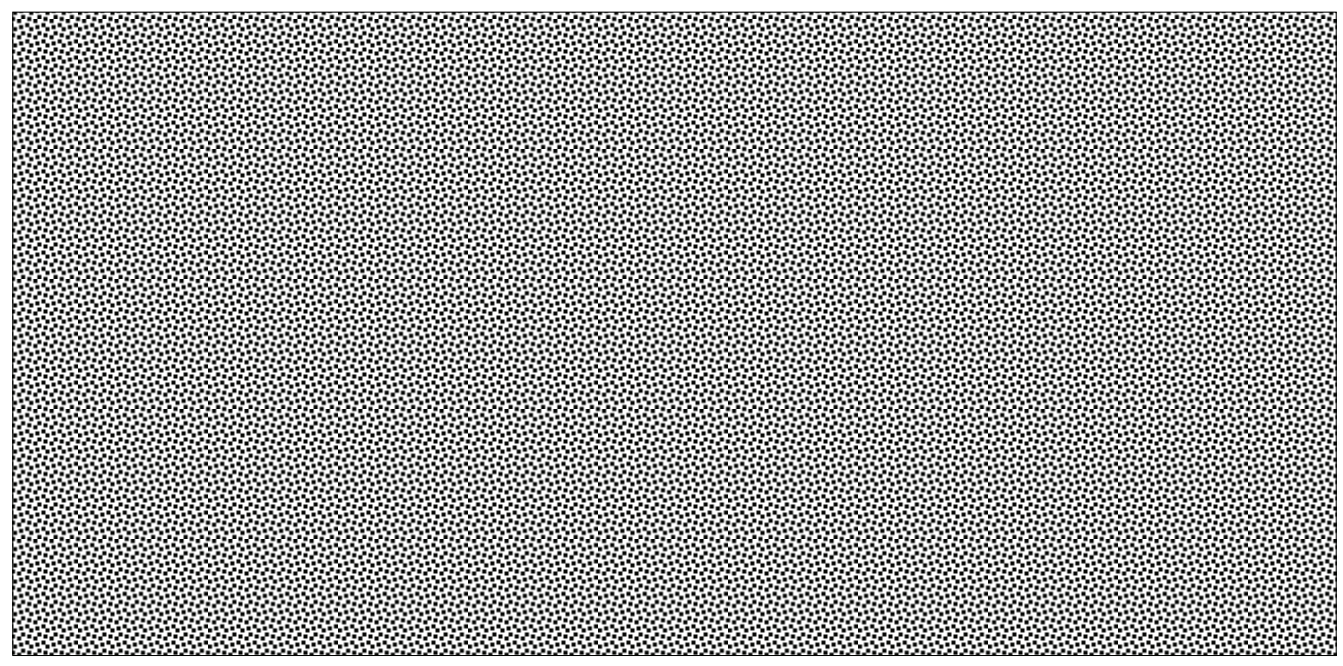

Figure 2: Comparison of percentage mass and embodied carbon of materials

Ready-mixed concrete contributed to $57.82 \%$ of total embodied carbon, mainly due to its high share of total material mass $(58.68 \%)$. Given the fact that a large proportion of Sri Lankan buildings are built with reinforced concrete and that total embodied energy and carbon of a building are proportional to the amount of materials used, a major factor which should be taken into consideration in construction decision making is the choice of construction practices and designs that save the quantities of materials.
Although reinforcement steel has a relatively low mass, it ranked first in embodied energy due to its high energy coefficient (32.69 $\mathrm{MJkg}^{-1}$ ). Despite having a share of $15.06 \%$ of total material mass, contribution of random rubble to total embodied carbon was significantly low, due to the low carbon coefficient value of rubble $\left(0.0022 \mathrm{kgCO}_{2} \mathrm{~kg}^{-1}\right)$. As biomass, which has a zerocarbon emission factor is the major energy source for production of clay bricks in Sri Lanka, bricks have negligible contribution to total embodied carbon 
$(0.01 \%)$. The main cement products, mortar and plaster shared $10.26 \%$ of embodied energy and $17.02 \%$ of embodied carbon. Although finishing materials such as ceramic tiles and paint were negligible in mass, their contribution to total embodied energy was significantly high at $10.39 \%$. Aluminium, which was used for the bulk of the doors and windows, has a much higher embodied carbon contribution (2.86\%) compared with other envelope materials such as bricks $(0.01 \%)$. As woodbased building products result in less energy use and low carbon footprint, the substitution of wood-based building materials for high energy and carbon intensive materials such as aluminium is beneficial from an environmental perspective (Dodoo et al., 2014).

Table 4: Contribution of building elements to total mass, embodied energy and carbon

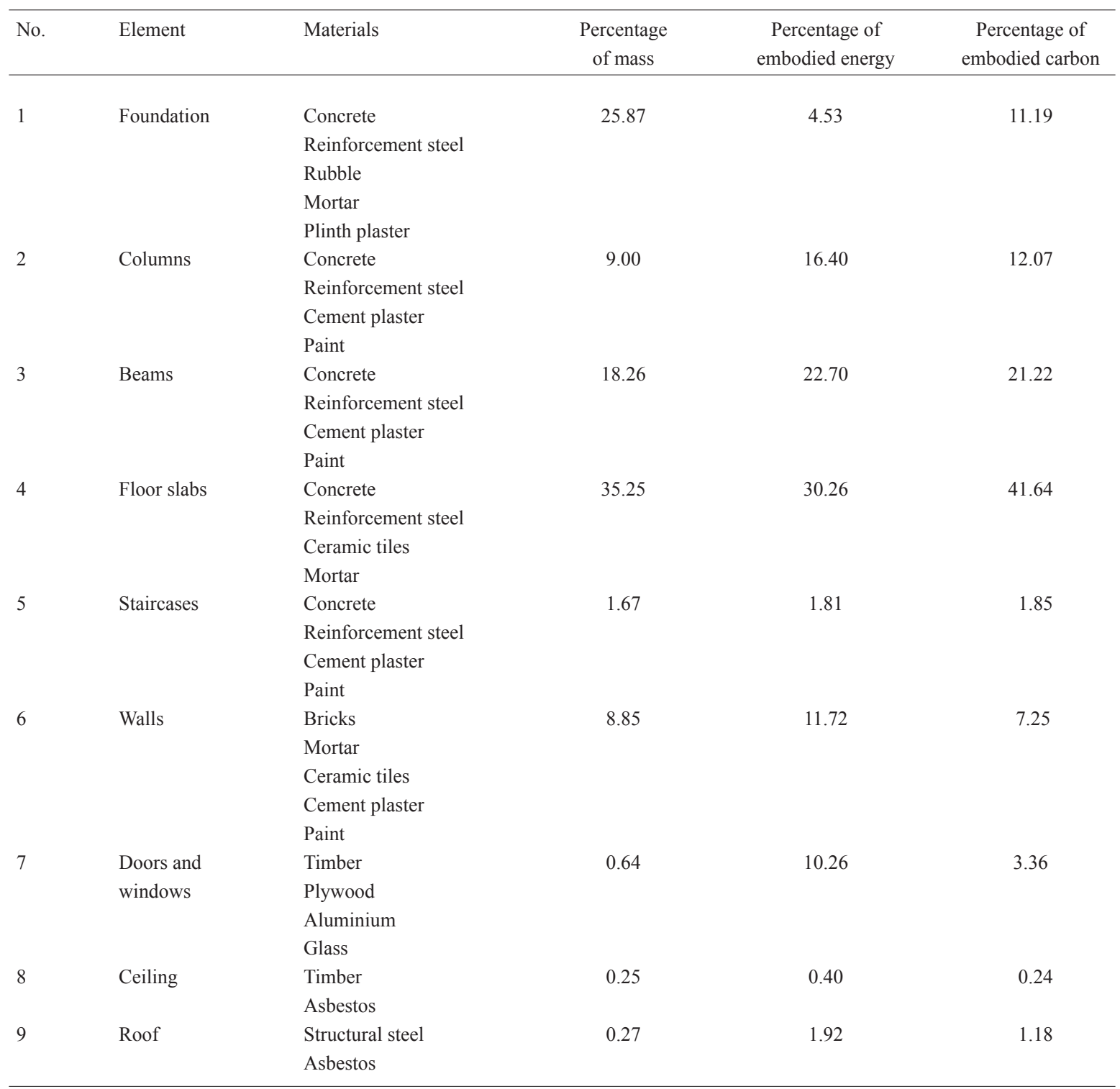

\section{Contribution of building elements}

In order to analyse embodied energy and carbon of the building with respect to main building elements such as foundation, columns, beams, floors, walls, roof, doors and windows the material quantities given in Table 3 were further disaggregated. The contributions of each element to total mass, embodied energy and embodied 
carbon of the building are given in Table 4. As it is a common practice to design buildings by elements rather than by building materials, the results presented in elemental form will facilitate building designers in evaluating life cycle environmental impacts of design alternatives.

The floor slabs have the highest share in material mass as well as embodied energy and carbon, which can be attributed to the high quantity of reinforced concrete used for slabs. Some authors reported similar results on reinforced concrete structures (Atmaca \& Atmaca, 2015). Structural elements such as foundation, floor slabs, columns and beams have high embodied energy and carbon, hence contributing to more than $73 \%$ of the total. Although the material mass of doors and windows is very low, they contributed highly to the total embodied energy and carbon as illustrated in Figure 3. This is mainly due to aluminium, which was used for the bulk of doors and windows. If the contribution of timber for doors and windows were higher, the embodied energy would have been reduced considerably.

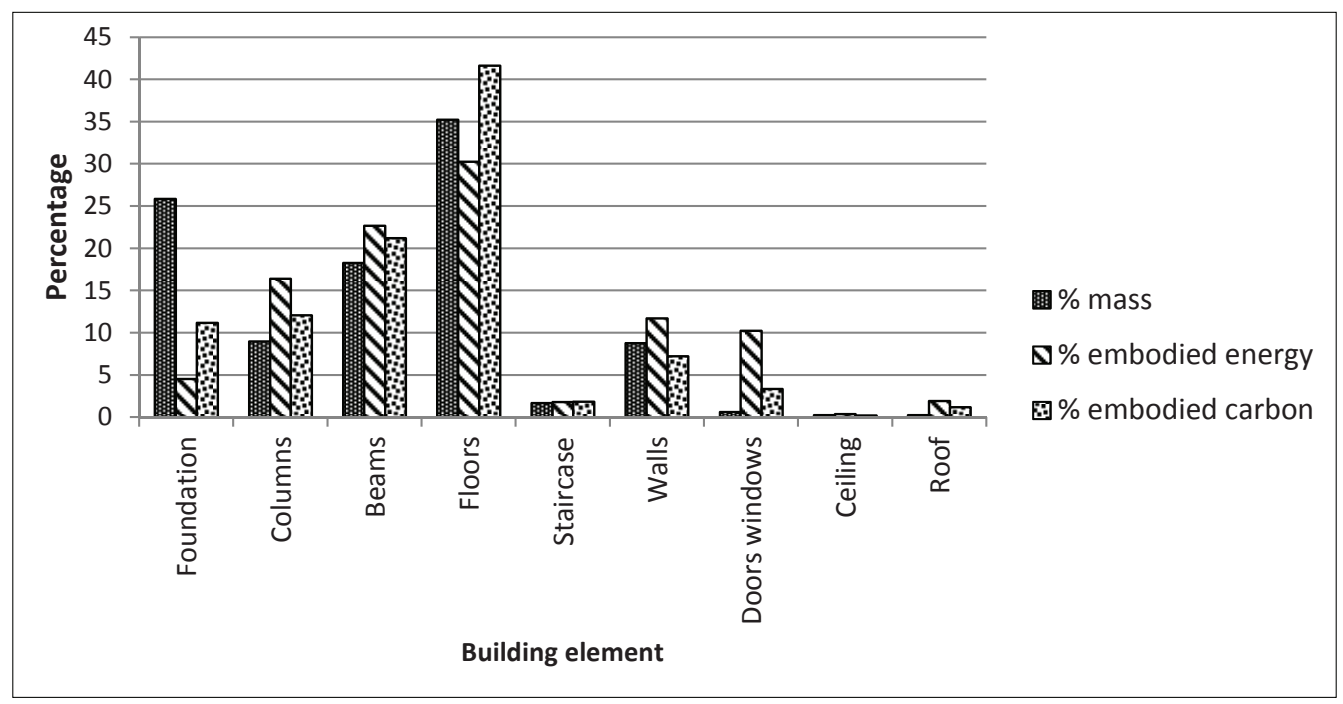

Figure 3: Comparison of percentage mass, embodied energy and carbon of building elements

\section{Total embodied energy and carbon of the building}

The total embodied energy and carbon of the case study building in the cradle-to-gate life cycle are 7,552.49 GJ and 451,331.99 $\mathrm{kgCO}_{2}$, respectively. By considering a functional unit of $1 \mathrm{~m}^{2}$ of gross floor area, embodied energy and carbon values were computed as $3.84 \mathrm{GJm}^{-2}$ and $229.34 \mathrm{kgCO}_{2} \mathrm{~m}^{-2}$, respectively. Many studies on the effect of different types of materials on the embodied energy and carbon of buildings have been conducted previously. A comparison of results of the current study with some of the previous studies are summarised in Table 5, which highlights the importance of selecting appropriate materials in order to facilitate low-energy and low-carbon buildings.

As given in Table 5, the embodied energy and carbon of reinforced concrete structures were found to be in the ranges of $1.93-10.0 \mathrm{GJm}^{-2}$ and
199.84 - $715.40 \mathrm{kgCO}_{2} \mathrm{~m}^{-2}$, respectively, which is quite comparable with the results of the current study. It illustrates the effect of different materials such as cast-in-situ and pre-fabricated concrete, steel, masonry and timber on embodied energy and carbon of a building.

\section{Use of alternative materials and technologies}

Use of alternative materials and technologies was identified as an effective approach in reducing embodied energy and carbon of buildings. Many previous studies emphasised the need to shift from conventional materials such as concrete, clay bricks, steel and aluminium to low-energy alternative materials, in order to save energy and reduce carbon emissions in buildings (Venkatarama Reddy \& Jagadish, 2003; Huberman \& Pearlmutter, 2008; Shukla et al., 2009; Venkatarama Reddy, 2009; Jayasinghe, 2011; Ramesh et al., 2012b). Several 
strategies were recommended in previous studies for developing sustainable, alternative building technologies; minimising use of high energy materials, minimising transportation, maximising use of local materials and resources, decentralised production, use of industrial and mine waste for building material production, recycling of building waste and use of renewable energy sources (Venkatarama Reddy, 2009).

Table 5: Comparison of results of embodied energy and carbon studies

\begin{tabular}{|c|c|c|c|c|c|c|}
\hline No. & Reference & $\begin{array}{l}\text { Building } \\
\text { type }\end{array}$ & Location & $\begin{array}{l}\text { Type of } \\
\text { structure }\end{array}$ & $\begin{array}{l}\text { Embodied } \\
\text { energy } \\
\left(\mathrm{GJm}^{-2}\right)\end{array}$ & $\begin{array}{l}\text { Embodied } \\
\text { carbon } \\
\left(\mathrm{kgCO}_{2} \mathrm{~m}^{-2}\right)\end{array}$ \\
\hline \multirow[t]{3}{*}{1} & \multirow[t]{3}{*}{ Fu et al., 2014} & \multirow[t]{3}{*}{$\mathrm{C}$} & \multirow[t]{3}{*}{ UK } & Brick and block & & \\
\hline & & & & masonry & - & 419.00 \\
\hline & & & & Timber frame & - & 349.00 \\
\hline 2 & Pinky Devi and Palaniappan, 2014 & $\mathrm{R}$ & India & $\begin{array}{l}\text { Reinforced concrete } \\
\text { frame and blocks }\end{array}$ & 8.1 & - \\
\hline 3 & Kofoworola and Gheewala, 2009 & $\mathrm{C}$ & Thailand & $\begin{array}{l}\text { Reinforced concrete } \\
\text { frame and bricks }\end{array}$ & 6.8 & - \\
\hline 4 & Wu et al., 2012 & $\mathrm{C}$ & China & $\begin{array}{l}\text { Reinforced concrete } \\
\text { frame and bricks }\end{array}$ & 8.43 & 715.40 \\
\hline \multirow[t]{2}{*}{5} & \multirow[t]{2}{*}{ Wen et al., 2015} & \multirow[t]{2}{*}{$\mathrm{R}$} & \multirow[t]{2}{*}{ Malaysia } & $\begin{array}{l}\text { Prefabricated } \\
\text { concrete (IBS) }\end{array}$ & 4.06 & 244.54 \\
\hline & & & & Cast-in-situ concrete & 5.94 & 276.93 \\
\hline \multirow[t]{3}{*}{6} & \multirow[t]{3}{*}{ Gong et al., 2012} & \multirow[t]{3}{*}{$\mathrm{R}$} & \multirow[t]{3}{*}{ China } & Concrete frame & - & 386.40 \\
\hline & & & & Steel frame & - & 133.64 \\
\hline & & & & Wood frame & - & 130.77 \\
\hline 7 & Ramesh et al., 2012b & $\mathrm{R}$ & India & Concrete and clay bricks & 7.83 & - \\
\hline 8 & Cho and Chae, 2016 & $\mathrm{R}$ & South Korea & Reinforced concrete & - & 459.93 \\
\hline \multirow[t]{2}{*}{9} & \multirow[t]{2}{*}{ You et al., 2011} & \multirow[t]{2}{*}{$\mathrm{R}$} & \multirow[t]{2}{*}{ China } & Masonry and concrete & - & 296.65 \\
\hline & & & & Steel and concrete & - & 284.21 \\
\hline \multirow[t]{2}{*}{10} & \multirow[t]{2}{*}{ Yu et al., 2011} & \multirow[t]{2}{*}{$\mathrm{R}$} & \multirow[t]{2}{*}{ China } & Concrete and bricks & 3.533 & 326.00 \\
\hline & & & & Bamboo structure & 3.003 & 169.00 \\
\hline 11 & Dimoudi and Tompa, 2008 & $\mathrm{C}$ & Greece & $\begin{array}{l}\text { Reinforced concrete } \\
\text { frame and bricks }\end{array}$ & 1.93 & 199.84 \\
\hline \multirow[t]{3}{*}{12} & \multirow[t]{3}{*}{ Suzuki and Oka, 1998} & \multirow[t]{3}{*}{$\mathrm{R}$} & \multirow[t]{3}{*}{ Japan } & Steel and RC & $8-10$ & - \\
\hline & & & & Lightweight steel & 4.5 & - \\
\hline & & & & Wood & 3.0 & - \\
\hline 13 & Current study & $\mathrm{R}$ & Sri Lanka & $\begin{array}{l}\text { Reinforced concrete } \\
\text { frame and bricks }\end{array}$ & 3.84 & 229.34 \\
\hline
\end{tabular}

C - commercial; R - residential

The embodied energy of various wall materials used in Sri Lanka; clay brick, cement masonry unit, cabook, rubble and wattle and daub were estimated and it was found that compared with embodied energy of clay bricks, the alternative materials have significantly low energy intensities (Emmanuel, 2004). A study conducted in Negev Desert region of Southern Israel revealed that by using alternative materials such as hollow concrete blocks, stabilised soil blocks and fly-ash blocks, embodied energy of a reinforced concrete building can be reduced by $30-40 \%$ (Huberman \& Pearlmutter, 2008). A comparison of embodied energy of various wall components investigated in previous studies is given in Table 6.

Although variations of values can be observed due to different locations of the studies conducted, the results gave evidence of stabilised mud blocks, stabilised rammed earth and cement stabilised soil blocks having only $20-48 \%$ of embodied energy of burnt clay bricks. As identified in a Sri Lankan study, a pre-cast reinforced concrete slab system is less energy intensive than a conventional reinforced concrete slab. Also, microconcrete roofing tile, which is an innovative alternative 
roofing material, has much less embodied energy than clay tiles and cement fibre sheets (Jayasinghe, 2011). In another Sri Lankan study, the embodied energy and carbon of purlins made of three different materials; timber, steel and pre-stressed concrete were analysed and timber was found to be the preferred option while steel was the least desirable with concrete in between (Dias \& Pooliyadda, 2004).

Table 6: Embodied energy of alternative masonry wall components

\begin{tabular}{|c|c|c|c|c|c|}
\hline \multirow[t]{2}{*}{ Masonry wall component } & \multicolumn{5}{|c|}{ Embodied energy (MJ per $10 \mathrm{~m}^{3}$ ) } \\
\hline & $\begin{array}{c}\text { Jayasinghe, } \\
2011\end{array}$ & $\begin{array}{c}\text { Huberman and } \\
\text { Pearlmutter, } \\
2008\end{array}$ & $\begin{array}{l}\text { Ramesh et al., } \\
2012\end{array}$ & $\begin{array}{l}\text { Venkatarama } \\
\text { Reddy, } 2009\end{array}$ & $\begin{array}{c}\text { Venkatarama } \\
\text { Reddy and } \\
\text { Jagadish, } 2003\end{array}$ \\
\hline Burnt clay brick & 3491 & & 2235 & $2000-3400$ & 2141 \\
\hline Stabilised mud block & 810 & & & $500-600$ & \\
\hline Stabilised rammed earth & 1663 & & & $450-600$ & \\
\hline Cement stabilised soil block & 960 & 938 & 646 & & $646-810$ \\
\hline Fly-ash block & & 184 & 1341 & $1000-1350$ & \\
\hline Autoclaved aerated concrete block & & 1536 & 818 & & \\
\hline Non-stabilised rammed earth & & & & $0-180$ & \\
\hline Steam-cured mud block & & & & & 65.2 \\
\hline
\end{tabular}

It was found that a bamboo-structure residential building has the potential of reducing $11 \%$ of embodied energy and $18.5 \%$ of embodied carbon when compared with a brick-concrete structure with identical functional requirements (Yu et al., 2011). The embodied energy of an adobe house in India was analysed and it was identified that compared to a similar built-up area of a conventional house made with burnt bricks, concrete and cement, the adobe house has $34 \%$ less embodied energy (Shukla et al., 2009).

\section{Reuse and recycling of materials}

Apart from the reduction of energy and carbon emissions, the need to save raw material resources was emphasised in literature. The opportunities for using industrial and mine waste for producing building materials such as bricks and blocks as well as substitute materials to replace fine aggregates and cement in concrete have been explored (Huberman \& Pearlmutter, 2008; Venkatarama Reddy, 2009).

In a number of previous studies, the significance of recycling, reusing and recovering of demolished building waste was emphasised. In a study to identify the options that can save embodied energy, recycling was found to have the highest energy saving potential of $53 \%$, while the energy saving potential of reusing was $6.2 \%$ and that of incineration was only $0.4 \%(\mathrm{Ng} \& \mathrm{Chau}, 2015)$. It was found that the use of demolished inorganic building materials and waste concrete powder as cement substitute materials results in a significant carbon emission reduction in the manufacturing process (Oh et al., 2014). The analysis of embodied energy of a building in Hong Kong indicated savings of more than $50 \%$ in embodied energy by using recycled steel and aluminium (Chen et al., 2001). Although reuse and recycling of steel, stone and timber from demolished structures takes place to some extent, recycling of materials such as broken bricks and blocks, concrete, aggregate and mortar are still not been conducted in an organised manner (Venkatarama Reddy, 2009). In Sri Lanka, reuse and recycling of construction and demolition waste is not much practiced at present, but with increasing awareness of waste as a valuable resource and introduction of technological know-how and standards, the current situation is expected to change in future (Kumara, 2009).

\section{CONCLUSION}

The cradle-to-gate life cycle energy and carbon emission of a multi-storey reinforced concrete residential building in a Sri Lankan university was assessed in the study. The embodied energy and carbon of the building were found to be $3.84 \mathrm{GJm}^{-2}$ and $229.34 \mathrm{kgCO}_{2} \mathrm{~m}^{-2}$, respectively. Reinforced concrete, the main structural material, contributed to $61.12 \%$ of total embodied energy and $70.74 \%$ of total embodied carbon. A similar effect was observed in reinforced concrete elements such as floor 
slabs, beams and columns. Although the secondary materials such as aluminium, ceramic tiles and paint represented an insignificant share of the total building mass, their contributions to embodied energy and carbon were significantly high. Doors and windows, which were constructed mainly from aluminium had a high share of embodied carbon irrespective of their lower material quantity. Therefore in design and material related decision making, materials which are used in buildings in mass quantities as well as materials with high energy intensities should be taken into account.

Embodied energy of buildings can vary over a wide range of values depending on the choice of building materials and building techniques. Many researchers have investigated the use of alternative building materials and technologies such as stabilised mud blocks, flyash blocks, stabilised rammed earth, blended cements, pre-fabricated roofing systems and filler slab roofs for minimising embodied energy and carbon of buildings. It was found that the embodied energy of a conventional building can be significantly reduced by introducing alternative building technologies. Whenever possible, energy intensive conventional building materials which are commonly used in Sri Lankan buildings should be replaced with appropriate alternatives in future building design. Also, promoting research on innovative and energy saving building materials and technologies will encourage researchers to investigate new options for alternatives.

At present, landfill is mainly used for disposal of construction and demolition waste in Sri Lanka and reuse and recycling of waste are not much practiced. With the increasing awareness of the importance of incorporating sustainability concepts in construction practices, reuse and recycling of demolition waste will be given much attention in future. Reuse and recycling of construction and demolition waste will result in saving energy and reduction of carbon emissions as well as reducing the amount of waste to be landfilled. The development of green labelling system for building materials has already been initiated in Sri Lanka. Although still in the developing stage, green labels will serve as a valuable instrument in identifying environmentally-friendly building materials for Sri Lankan buildings. With future developments of innovative, cost-effective and lowenergy local materials, the green labels will support the construction professionals in making material related decisions.

In future, studies of different categories of residential buildings, as well as commercial buildings should be conducted and their impact on energy consumption and carbon emission should be investigated. Also, extension of the study by considering the whole life cycle of buildings in cradle-to-grave analysis will be highly beneficial. In estimating embodied energy and carbon coefficients of materials, previous researchers considered material manufacturing technologies, energy sources and electricity generation mix of the country prevailing at the time of respective studies. As these factors vary with time, periodic examination and revision of data to reflect the respective changes is highly necessary. The development of a national embodied energy and carbon coefficient database for building materials is a timely requirement and such a database will facilitate more accurate assessment of embodied energy and carbon of buildings in Sri Lanka.

\section{Acknowledgement}

The authors gratefully acknowledge the authorities of the General Sir John Kotelawala Defence University, Sri Lanka and the Central Engineering Consultancy Bureau (CECB), Sri Lanka for providing the valuable information needed for this research work.

\section{REFERENCES}

Abeysundara U.G.Y., Babel S. \& Gheewala S.H. (2009). A matrix in life cycle perspective for selecting sustainable materials for buildings in Sri Lanka. Building and Environment 44(5): 997 - 1004.

DOI: http://dx.doi.org/10.1016/j.buildenv.2008.07.005

Asif M., Muneer T. \& Kelley R. (2007). Life cycle assessment: a case study of a dwelling home in Scotland. Building and Environment 42(3): 1391 - 1394.

DOI: https://doi.org/10.1016/j.buildenv.2005.11.023

Atmaca A. \& Atmaca N. (2015). Life cycle energy (LCEA) and carbon dioxide emissions $\left(\mathrm{LCCO}_{2} \mathrm{~A}\right)$ assessment of two residential buildings in Gaziantep, Turkey. Energy and Buildings 102: 417 - 431.

DOI: https://doi.org/10.1016/j.enbuild.2015.06.008

Biswas W.K. (2014). Carbon footprint and embodied energy assessment of building construction works in Western Australia. International Journal of Sustainable Built Environment 3: 179 - 186.

DOI: https://doi.org/10.1007/s11367-013-0681-2

Chau C.K., Leung T.M. \& Ng W.Y. (2015). A review on life cycle assessment, life cycle energy assessment and life cycle carbon emissions assessment on buildings. Applied Energy 143(1): 395 - 413.

DOI: https://doi.org/10.1016/j.apenergy.2015.01.023

Chau C.K., Yik F.W.H., Hui W.K., Liu H.C. \& Yu H.K. (2007). Environmental impacts of building materials and building services components for commercial buildings in Hong Kong. Journal of Cleaner Production 15(18): 1840 - 1851. DOI: https://doi.org/10.1016/j.jclepro.2006.10.004

Chen T., Burnett J. \& Chau C. (2001). Analysis of embodied 
energy use in the residential building of Hong Kong. Energy 26(4): 323 - 340.

Cho S.H. \& Chae C.U. (2016). A study on life cycle $\mathrm{CO}_{2}$ emissions of low-carbon building in South Korea. Sustainability (Switzerland) 8(6): $1-19$.

DOI: https://doi.org/10.3390/su8060579

Department of Census and Statistics Sri Lanka (2015). Survey of Construction Industries 2013. Department of Census and Statistics Sri Lanka, Battaramulla, Sri Lanka.

Dias W.P.S. \& Pooliyadda S.P. (2004). Quality based energy contents and carbon coefficients for building materials: a systems approach. Energy 29(4): 561 - 580.

DOI: https://doi.org/10.1016/j.energy.2003.10.001

Dimoudi A. \& Tompa C. (2008). Energy and environmental indicators related to construction of office buildings. Resources, Conservation and Recycling 53(1 - 2): 86 - 95.

Dodoo A., Gustavsson L. \& Sathre R. (2014). Lifecycle carbon implications of conventional and low-energy multi-storey timber building systems. Energy and Buildings 82: $194-$ 210.

DOI: https://doi.org/10.1016/j.enbuild.2014.06.034

Emmanuel R. (2004). Estimating the environmental suitability of wall materials: preliminary results from Sri Lanka. Building and Environment 39(10): 1253 - 1261.

DOI: https://doi.org/10.1016/j.buildenv.2004.02.012

European Commission (2016). $\mathrm{CO}_{2}$ Time Series 1990 - 2015 per Region/Country. Joint Research Centre-Emissions Database for Global Atmospheric Research (EDGAR). Available at http://edgar.jrc.ec.europa.eu/overview. php? $v=$ CO2ts 1990-2015, Accessed 27 March 2017.

Fu F., Luo H., Zhong H. \& Hill A. (2014). Development of a carbon emission calculations system for optimizing building plan based on the LCA framework. Mathematical Problems in Engineering 2014: Article ID 653849. DOI: https://doi.org/10.1155/2014/653849

Gong X., Nie Z., Wang Z., Cui S., Gao F. \& Zuo T. (2012). Life cycle energy consumption and carbon dioxide emission of residential building designs in Beijing: a comparative study. Journal of Industrial Ecology 16(4): 576 - 587. DOI: https://doi.org/10.1111/j.1530-9290.2011.00415.x

González M.J. \& García Navarro J. (2006). Assessment of the decrease of $\mathrm{CO}_{2}$ emissions in the construction field through the selection of materials: practical case study of three houses of low environmental impact. Building and Environment 41(7): 902 - 909.

DOI: https://doi.org/10.1016/j.buildenv.2005.04.006

Hammond G. \& Jones C. (2011). Inventory of Carbon and Energy (ICE) version 2.0. Sustainable Energy Research Team (SERT), Department of Mechanical Engineering, University of Bath, UK.

Hong J., Shen G.Q., Feng Y., Lau W.S. \& Mao C. (2015). Greenhouse gas emissions during the construction phase of a building: a case study in China. Journal of Cleaner Production 103(July 2016): 249 - 259.

Huberman N. \& Pearlmutter D. (2008). A life-cycle energy analysis of building materials in the Negev desert. Energy and Buildings 40(5): $837-848$.

DOI: https://doi.org/10.1016/j.enbuild.2007.06.002
Intergovernmental Panel on Climate Change (IPCC) (2007). Climate Change 2007: Synthesis Report. Contribution of Working Groups I, II and III to the Forth Assessment Report of the Intergovernmental Panel on Climate Change, Core Writing Team (eds. R.K. Pachauri \& A. Reisinger). Intergovernmental Panel on Climate Change, Geneva, Switzerland.

International Organization for Standardization (ISO) (1997). ISO 14040-Environmental management - Life Cycle Assessment - Principles and Framework.

Jayasinghe C. (2011). Embodied energy of alternative building materials and their impact on life cycle cost parameters. International Conference on Structural Engineering, Kandy, Sri Lanka, 15 - 17 December, pp. $1-20$.

Kofoworola O.F. \& Gheewala S.H. (2008). Environmental life cycle assessment of a commercial office building in Thailand. International Journal of Life Cycle Assessment 13(6): 498 - 511.

DOI: https://doi.org/10.1007/s11367-008-0012-1

Kofoworola O.F. \& Gheewala S.H. (2009). Life cycle energy assessment of a typical office building in Thailand. Energy and Buildings 41(10): 1076 - 1083.

DOI: https://doi.org/10.1016/j.enbuild.2009.06.002

Kumara T. (2009). Construction and demolition waste management practices of building projects in Sri Lanka. MBA thesis, University of Moratuwa, Sri Lanka.

Ng W.Y. \& Chau C.K. (2015). New life of the building materials-recycle, reuse and recovery. Energy Procedia 75: $2884-2891$.

DOI: https://doi.org/10.1016/j.egypro.2015.07.581

Oh D.Y., Noguchi T., Kitagaki R. \& Park W.J. (2014). $\mathrm{CO}_{2}$ emission reduction by reuse of building material waste in the Japanese cement industry. Renewable and Sustainable Energy Reviews 38: 796 - 810.

DOI: https://doi.org/10.1016/j.rser.2014.07.036

Pinky Devi L. \& Palaniappan S. (2014). A case study on life cycle energy use of residential building in Southern India. Energy and Buildings 80: 247 - 259.

DOI: https://doi.org/10.1016/j.enbuild.2014.05.034

Pooliyadda S.P. (2000). Energy content and carbon emission audit of building materials. MPhil thesis, University of Moratuwa, Sri Lanka.

Ramesh T., Prakash R. \& Shukla K.K. (2012a). Life cycle approach in evaluating energy performance of residential buildings in Indian context. Energy and Buildings 54: $259-265$.

DOI: https://doi.org/10.1016/j.enbuild.2012.07.016

Ramesh T., Prakash R. \& Shukla K.K. (2012b). Life cycle energy analysis of a residential building with different envelopes and climates in Indian context. Applied Energy 89(1): $193-202$.

DOI: https://doi.org/10.1016/j.apenergy.2011.05.054

Ruuska A. (2013). Role of embodied energy, operational energy and related greenhouse gas emission of buildings in the context of developing tropical countries. SB13 SingaporeRealising Sustainability in Tropics, pp. $205-211$.

Shukla A., Tiwari G.N. \& Sodha M.S. (2009). Embodied energy analysis of adobe house. Renewable Energy 34(3): 
$755-761$.

DOI: https://doi.org/10.1016/j.renene.2008.04.002

Suzuki M. \& Oka T. (1998). Estimation of life cycle energy consumption and $\mathrm{CO}_{2}$ emission of office buildings in Japan. Energy and Buildings 28(1): 33 - 41.

United Nations Environmental Programme (UNEP) (2009). Buildings and Climate Change: Summary for Decision Makers. United Nations Environmental Programme, Nairobi, Kenya.

Varun., Sharma A., Shree V. \& Nautiyal H. (2012). Life cycle environmental assessment of an educational building in Northern India: a case study. Sustainable Cities and Society 4(1): $22-28$. DOI: https://doi.org/10.1016/j.scs.2012.03.002

Venkatarama Reddy B. \& Jagadish K. (2003). Embodied energy of common and alternative building materials and technologies. Energy and Buildings 35(2): 129 - 137.

Venkatarama Reddy B.V. (2009). Sustainable materials for low carbon buildings. International Journal of Low-Carbon Technologies 4(3): $175-181$.

DOI: https://doi.org/10.1093/ijlct/ctp025
Wen T.J., Siong H.C. \& Noor Z.Z. (2015). Assessment of embodied energy and global warming potential of building construction using life cycle analysis approach: case studies of residential buildings in Iskandar Malaysia. Energy and Buildings 93: 295 - 302.

DOI: https://doi.org/10.1016/j.enbuild.2014.12.002

Wu H.J., Yuan Z.W., Zhang L. \& Bi J. (2012). Life cycle energy consumption and $\mathrm{CO}_{2}$ emission of an office building in China. International Journal of Life Cycle Assessment 17(2): $105-118$.

DOI: https://doi.org/10.1007/s11367-011-0342-2

You F., Hu D., Zhang H., Guo Z., Zhao Y., Wang B. \& Yuan Y. (2011). Carbon emissions in the life cycle of urban building system in China - a case study of residential buildings. Ecological Complexity 8(2): $201-212$.

DOI: https://doi.org/10.1016/j.ecocom.2011.02.003

Yu D., Tan H. \& Ruan Y. (2011). A future bamboo-structure residential building prototype in China: life cycle assessment of energy use and carbon emission. Energy and Buildings 43(10): 2638 - 2646.

DOI: https://doi.org/10.1016/j.enbuild.2011.06.013 